Vegetalika. 2019. 8(4): 251-262

\title{
Pengembangan Metode Penyaringan Klon Tebu Tahan Kering Menggunakan Metode Pengendalian Kadar Lengas
}

\section{Development of Dry Sugar Cane Cloning Method Using Hydration Control Method}

\author{
Yasinta Bibiana R.P.P., Taryono*), Rani Agustina Wulandari \\ Departemen Budidaya Pertanian, Fakultas Pertanian, Universitas Gadjah Mada \\ *) Penulis untuk koresponden Email: tariono60@ugm.ac.id@ugm.ac.id
}

\begin{abstract}
Sugarcane is one of sugar producing plants in Indonesia. The area of sugarcane in irrigated rice fields in Java is decreasing. Now the area of sugarcane in the paddy field left about $40 \%$, the rest has moved to dry land. In the germination phase, the crop water requirement is low, then begins to increase in the tillering phase and reaches its peak in the stem extension phase. The purpose of this study will see the endurance of sugarcane seedlings to the stress during the germination phase and the process of recovery during the growth phase. The study was conducted from May to September 2016 at agriculture land of Banguntapan, Faculty of Agriculture, Universitas Gadjah Mada. Experiment Design used ithe Randomized Completed Design (RCD) with 2 factors. The first factor was moisture content consisting of 4 levels such as $100 \%, 80 \%, 60 \%$, and $40 \%$. The second factor was the sugarcane clones of PS 862, PS 864, Kidang Kencana (KK), Bululawang $(B L)$, and VMC 76-16. The results showed that moisture treatment was able to influence the growth of sugarcane plants decreasing growth rate of some clones when the moisture content was $40 \%$. Kidang Kencana seems to be the most sensitive to drought stress.
\end{abstract}

Keywords: sugarcane, moisture content, clone

\section{INTISARI}

Tebu merupakan salah satu tanaman penghasil gula di Indonesia. Luas areal tebu di lahan sawah beririgasi di Jawa semakin berkurang. Kini areal tebu di lahan sawah tinggal sekitar $40 \%$, selebihnya telah beralih ke lahan kering. Pada fase perkecambahan, kebutuhan air tanaman rendah, kemudian mulai meningkat pada fase pertunasan dan mencapai puncaknya pada fase pemanjangan batang. Tujuan penelitian ini, akan dilihat ketahanan bibit tebu terhadap cekaman saat fase perkecambahan dan proses beradaptasinya kembali tebu saat fase pertumbuhan tunas dari kondisi tercekam. Penelitian dilakukan pada bulan Mei hingga September 2016 di Kebun Percobaan Banguntapan, Fakultas Pertanian, Universitas Gadjah Mada. Rancangan Percobaan yang digunakan yaitu Rancangan Acak Lengkap (RAL) dengan 2 faktor. Faktor pertama yaitu kadar lengas yang terdiri dari 4 aras yaitu 100\%, 80\%, 60\%, dan 40\%. Faktor kedua adalah klon tebu yaitu klon PS 862, PS 864, Kidang Kencana (KK), Bululawang (BL), dan VMC 76-16. Hasil menunjukkan bahwa perlakuan pengaturan kadar lengas mampu mempengaruhi pertumbuhan tebu dengan menurunnya angka pertumbuhan beberapa 
klon ketika kadar lengas $40 \%$. Klon KK menjadi klon yang memiliki hasil terendah dan teruji rentan terhadap perlakuan cekaman kekeringan.

Kata kunci: tebu, kadar lengas, klon

\section{PENDAHULUAN}

Tebu merupakan tanaman penghasil gula. Di Indonesia, tanaman ini menjadi salah satu tanaman perkebunan yang banyak dibudidayakan. Tebu merupakan spesies paling penting dalam genus Saccharum karena kandungan sukrosanya paling tinggi dan kandungan seratnya paling rendah. Tebu mempunyai sosok yang tinggi kurus, tidak bercabang dan tumbuh tegak. Tanaman yang tumbuh baik, tinggi batangnya dapat mencapai 3 - 5 meter atau lebih (Wijayanti, 2008).

Luas areal tebu di lahan sawah beririgasi di Jawa semakin berkurang. Kini areal tebu di lahan sawah tinggal sekitar $40 \%$, selebihnya telah beralih ke lahan kering (Anonim, 2003). Menurut data sumberdaya lahan eksplorasi yang mencakup seluruh Indonesia (Puslitbangtanak, 2000), data tanah tinjau (BBSDLP, 2012), dan data tipe iklim Indonesia (Balitklimat, 2003) setelah dianalisis oleh Mulyani \& Syarwani (2013), menunjukkan jumlah lahan kering yang optimal bagi pertanian namun belum dimanfaatkan di Indonesia sebesar 70.409 .742 hektar. Di pulau Jawa sendiri terdapat 199.500 hektar lahan kering yang belum dimanfaatkan. Dari data tersebut menunjukkan bahwa masih banyak lahan di Indonesia yang belum dimanfaatkan.

Tebu tumbuh pada berbagai tekstur tanah mulai dari pasir hingga lempung, tetapi yang terpenting yaitu tebu harus tumbuh pada kondisi dengan tanah memiliki hara makro berlimpah. Tebu juga tahan terhadap kondisi $\mathrm{pH}$ antara 4,5-8. Tebu dapat tumbuh di daerah tropis dan subtropis dengan masalah utama ketersediaan air baik kekurangan (kekeringan) maupun kelebihan (drainase buruk). Lahan berdrainase lancar dengan ketersediaan air cukup sangat sesuai untuk menghindari terjadinya genangan terutama pada fase kemasakan. Tebu memiliki 4 tahap dalam pertumbuhannya, yaitu perkecambahan, pembentukan tunas, pengembangan batang, pemasakan. Pada saat tanam, kondisi tanah harus cukup lembab (50\% kandungan air tanah tersedia). Pada fase perkecambahan, kebutuhan air tanaman rendah, kemudian mulai meningkat pada fase pertunasan dan mencapai puncaknya pada fase pemanjangan batang atau pertumbuhan cepat, dan mulai menurun pada fase kemasakan sampai panen (Riajaya, 2016). 
Penanaman tebu dapat dilakukan pada musim kemarau apabila ditanam pada lahan basah dan dilakukan pada saat memasuki musim penghujan apabila ditanam pada lahan kering. Jumlah air yang dibutuhkan pada fase awal tumbuh lebih sedikit daripada saat fase pemanjangan batang, sehingga tidak membutuhkan penyiraman yang konstan. Efisiensi penggunaan air pada kondisi air tanah $80 \%$ di berbagai wilayah di dunia dilaporkan oleh FAO sebesar 5-8 $\mathrm{kg}$ tebu/ $\mathrm{m}^{3}$ air dan 0,6-1 $\mathrm{kg}$ sukrosa $/ \mathrm{m}^{3}$ air (Riajaya, 2016). Namun, kenyataan di lapangan sulit untuk mendapatkan kondisi optimum pada setiap fase pertumbuhan tebu. Dengan adanya permasalahan tersebut, maka diperlukan adanya bibit yang mampu bertahan terhadap kondisi tercekam kekeringan. Pada penelitian ini, akan dilihat ketahanan bibit tebu terhadap cekaman saat fase perkecambahan dan fase pertumbuhan tunas.

\section{BAHAN DAN METODE PENELITIAN}

Penelitian dilaksanakan pada bulan Mei - September 2016 di Kebun percobaan Banguntapan, Fakultas Pertanian, Universitas Gadjah Mada. Bahan yang digunakan pada penelitian yaitu 5 klon tebu (PS 862, PS 864, Kidang Kencana, VMC 76-16, Bululawang), pasir, arang sekam, air, dithane. Alat-alat yang digunakan yaitu bak perkecambahan, gelas ukur, ember, polibag, timbangan, oven, penggaris, alat tulis.

Penelitian akan dilakukan dengan menggunakan metode percobaan. Percobaan ini dilakukan melalui 2 tahap, yaitu tahap perkecambahan dan tahap pertumbuhan tunas. Perlakuan terdiri dari 2 faktor yaitu kadar lengas dan klon. Tahap pertama atau tahap perkecambahan (I) akan dilakukan selama 1 bulan di rumah kaca. Proses perkecambahan dimulai dengan perlakuan kadar lengas media tumbuh. Perlakuan kadar lengas media tumbuh dibedakan menjadi 4 macam kadar lengas yaitu 100\% (J1), 80\% (J2), 60\% (J3), dan $40 \%$ (J4). Bahan tanam yang digunakan merupakan mata tunas tunggal (budchip) tebu dari 5 klon tebu yaitu PS 862 (K1), PS 864 (K2), Kidang Kencana (KK) (K3), Bululawang (BL) (K4), VMC 76-16 (K5). Media yang digunakan pada fase perkecambahan yaitu bak perkecambahan yang berjumlah 60 . Tiap bak diisi 20 benih tebu dengan klon yang sama. Kadar lengas (4 aras) dicobakan menggunakan 5 klon dalam Rancangan Acak Lengkap (RAL) dengan 3 ulangan,. Selama dalam masa perkecambahan dipilih 3 tanaman dari setiap perlakuan sebagai tanaman contoh atau sampel. Setiap minggunya tanaman contoh diukur tinggi tanaman dan jumlah daunnya. Selain itu, dilakukan pula 
penghitungan bibit yang tumbuh dan yang mati. Setelah bibit berumur 1 bulan, dilakukan pindah tanam di lahan. Sebelum dilakukan pindah tanam, diambil 3 tanaman tiap kombinasi perlakuan sebagai tanaman korban dan diukur sesuai dengan sifat mutu benihnya.

Tahap kedua (II) dalam percobaan ini yaitu mengevaluasi pengaruh kadar lengas terhadap pertumbuhan tunas. Tanaman yang digunakan pada tahap kedua ini adalah bibit yang berasal dari percobaan tahap pertama. Sesuai dengan percobaan tahap pertama, terdapat 20 kombinasi perlakuan yang ditata dalam RAL dengan 3 ulangan. Meskipun demikian jumlah bibit yang dipindah tanam sebanyak 9 tanaman per perlakuan dengan rincian 3 tanaman contoh, 3 tanaman korban, dan 3 tanaman cadangan.

Bibit yang dipindah tanam merupakan bibit yang tumbuh berdasarkan perlakuan kadar lengas. Bibit yang dipilih juga merupakan bibit yang tumbuh seragam tiap perlakuan. Jumlah bibit yang dipindahkan yaitu 9 tanaman tiap perlakuan kombinasinya. Penanaman dilakukan dengan menggunakan polibag. Selama penanaman di lahan, pemeliharaan dilakukan dengan pemberian pupuk dan penyiraman. Penyiraman dilakuan setiap hari dengan takaran yang sama tiap perlakuan. Setelah 3 bulan, tanaman contoh dan tanaman korban dipanen dan diukur sesuai dengan parameter yang sudah ditentukan.

\section{HASIL DAN PEMBAHASAN}

Pengaturan kadar lengas sangat mempengaruhi pertumbuhan tanaman khususnya daya berkecambah dan akar pada tanaman ketika tahap awal pertumbuhan. Pada tebu sendiri, saat awal pertumbuhan merupakan saat-saat penting dalam membutuhkan asupan air yang cukup. Ketika akar dapat tumbuh dengan baik, maka asupan hara yang akan dialirkan ke batang tidak akan terganggu.

Gaya berkecambah merupakan kemampuan tanaman untuk tumbuh dalam satu populasi. Gaya berkecambah didapatkan dengan membagi jumlah individu yang berkecambah dengan jumlah individu yang ditanam. Nilai gaya berkecambah klon KK memiliki nilai terendah yaitu $55,41 \%$. Pada tanah kering atau kekurangan air, klon KK akan cenderung tidak tumbuh atau terdapat pengurangan populasi. Dibandingkan ke 4 klon lainnya yang lebih tahan terhadap cekaman, klon KK akan lebih tumbuh optimal pada kondisi lahan yang memiliki kadar liat tidak terlalu tinggi dan perairan lancar (P3Gl, 2007). Sedangkan untuk kadar lengas (tabel 1), kadar lengas 40\% memiliki nilai gaya 
berkecambah paling kecil dibandingkan dengan kadar lengas lainnya dan kadar lengas $100 \%$ memiliki nilai yang tertinggi. Hal ini sejalan dengan teori yang dikatakan oleh Gardner et al. (1991) bahwa selama pertumbuhan tunas dan akar, sel aktif melakukan proses pembelahan dan pemanjangan. Pada proses pembelahan dan pemanjangan sel tersebut kebutuhan air bagi tanaman mengalami peningkatan dan tanaman sangat riskan terhadap kekurangan air.

Tabel 1. Pengaruh kadar lengas dan klon tebu pada tahap persemaian terhadap gaya berkecambah tanaman (\%)

\begin{tabular}{|c|c|c|c|c|c|c|}
\hline \multirow{2}{*}{$\begin{array}{c}\text { Kadar Lengas } \\
(\%)\end{array}$} & \multicolumn{5}{|c|}{ Klon } & \multirow[b]{2}{*}{ Rerata } \\
\hline & PS 862 & PS 864 & KK & $\mathrm{BL}$ & VMC 76-16 & \\
\hline 100 & 98.33 & 98.33 & 75.00 & 75.00 & 96.67 & $90.00 \mathrm{a}$ \\
\hline 80 & 100.00 & 88.33 & 56.67 & 81.67 & 100.00 & $85.33 a$ \\
\hline 60 & 96.67 & 91.67 & 50.00 & 80.00 & 96.67 & $83.00 \mathrm{~b}$ \\
\hline 40 & 95.00 & 81.67 & 40.00 & 85.00 & 95.00 & $79.33 \mathrm{~b}$ \\
\hline Rerata & $97.50 a$ & $88.75 \mathrm{~b}$ & $55.41 \mathrm{c}$ & $83.33 \mathrm{~b}$ & $97.08 a$ & $(-)$ \\
\hline CV (\%) & \multicolumn{6}{|c|}{9,88} \\
\hline
\end{tabular}

Berdasarkan tabel 2, tidak ada interaksi antar perlakuan namun terdapat perlakuan beda nyata pada faktor kadar lengas. Kadar lengas $40 \%$ memiliki rerata nilai terendah dibandingkan kadar lengas lainnya. Namun panjang akar terendah dimiliki klon VMC 7616 pada kadar lengas $60 \%$. Nilai CV panjang akar ini terbilang tinggi yang artinya bahwa banyak faktor yang mempengaruhi pertumbuhan akar tanaman. Salah satu mekanisme ketahanan terhadap adanya cekaman kekeringan adalah menghindar dari kondisi cekaman tersebut. Mekanisme morfofisiologis tanaman untuk menghindar dari cekaman kekeringan adalah adanya kemampuan tanaman memanjangkan akarnya untuk mencari sumber air jauh dari permukaan tanah pada saat terjadi cekaman kekeringan di area dekat permukaan tanah (Onwueme, 1978). Pada saat kekurangan air pertumbuhan sistem perakaran umumnya meningkat, sedangkan pertumbuhan tajuk menurun. 
Tabel 2. Pengaruh kadar lengas dan klon tebu pada tahap persemaian terhadap panjang akar tebu 4 mst $(\mathrm{cm})$

\begin{tabular}{ccccccc}
\hline \multirow{2}{*}{$\begin{array}{c}\text { Kadar Lengas } \\
(\%)\end{array}$} & PS 862 & PS 864 & KK & BL & VMC 76-16 & Rerata \\
\cline { 2 - 6 } & 3.43 & 3.49 & 3.59 & 3.43 & 4.73 & $3.73 \mathrm{a}$ \\
80 & 3.77 & 3.20 & 3.37 & 3.62 & 3.78 & $3.55 \mathrm{a}$ \\
60 & 3.17 & 3.03 & 3.13 & 4.16 & 2.60 & $3.22 \mathrm{~b}$ \\
40 & 3.01 & 2.63 & 2.70 & 3.22 & 3.32 & $2.97 \mathrm{~b}$ \\
\hline Rerata & $3.34 \mathrm{a}$ & $3.08 \mathrm{a}$ & $3.19 \mathrm{a}$ & $3.60 \mathrm{a}$ & $3.60 \mathrm{a}$ & $(-)$ \\
\hline CV (\%) & & \multicolumn{7}{c}{22,53} \\
\hline
\end{tabular}

Keterangan: Angka pada kolom atau baris diikuti oleh huruf yang sama tidak berbeda nyata pada uji Scott-Knott dengan tingkat signifikasi 95\%.

Akar merupakan organ yang menyerap sumber makanan dan menyimpan hasil fotosintesis tanaman. Akar yang kekurangan nutrisi akan memiliki bobot akar maupun bobot kering yang kecil. Faktor yang mempengaruhi pola sebaran akar antara lain : penghalang mekanis, suhu tanah, aerasi, ketersedian hara dan air. Pengukuran berat segar akar ini adalah untuk mengetahui seberapa besar air yang terkandung dalam akar tanaman tersebut.

Pada fase perkecambahan yang ditunjukkan pada tabel 2, panjang akar tidak menunjukkan adanya beda nyata antar klon. Faktor yang dapat mengengaruhi adanya perbedaan ketika fase perkecambahan dengan fase pertumbuhan tunas yaitu media tanam yang berbeda baik dari segi luasannya dan persaingannya. Pada saat perkecambahan, bibit ditanam pada bak yang berisi 20 bibit, sedangkan saat fase pertumbuhan tunas, bibit ditanam pada polybag yang tiap polybag nya hanya berisi 1 tanaman. Persaingan yang tidak begitu besar yang akhirnya membuat tanaman berusaha menggunakan unsur hara dalam tanah dengan maksimal dan berkurangnya faktor cekaman air membuat tanaman mengadaptasi kembali dengan kondisi normal.

Volume akar juga merupakan salah satu parameter yang mampu melihat kondisi tercekam suatu tanaman. Berbeda dengan akar yang akan semakin panjang ketika kondisi tercekam, maka pada akar yang tercekam volumenya akan menjadi lebih kecil dikarenakan kondisi akar yang tercekam memiliki kandungan air yang sedikit didalam tubuh akar. 
Bibiana et al., / Vegetalika. 2019. 8(4): 251-262

Tabel 3. Pengaruh kadar lengas dan klon tebu pada tahap persemaian terhadap volume akar umur $4 \mathrm{mst}\left(\mathrm{cm}^{3}\right)$

\begin{tabular}{ccccccc}
\hline \multirow{2}{*}{$\begin{array}{c}\text { Kadar Lengas } \\
(\%)\end{array}$} & PS 862 & PS 864 & KK & BL & VMC 76-16 & Rerata \\
\cline { 2 - 6 } & $1.35 \mathrm{a}$ & $1.30 \mathrm{a}$ & $1.30 \mathrm{a}$ & $1.37 \mathrm{a}$ & $1.35 \mathrm{a}$ & 1.33 \\
80 & $1.36 \mathrm{a}$ & $1.35 \mathrm{a}$ & $1.28 \mathrm{a}$ & $1.34 \mathrm{a}$ & $1.36 \mathrm{a}$ & 1.33 \\
60 & $1.21 \mathrm{c}$ & $1.32 \mathrm{a}$ & $1.17 \mathrm{c}$ & $1.34 \mathrm{a}$ & $1.34 \mathrm{a}$ & 1.28 \\
40 & $1.26 \mathrm{~b}$ & $1.26 \mathrm{~b}$ & $1.20 \mathrm{c}$ & $1.30 \mathrm{a}$ & $1.30 \mathrm{a}$ & 1.26 \\
\hline Rerata & 1.29 & 1.31 & 1.24 & 1.336 & 1.340 & $(+)$ \\
\hline CV (\%) & & \multicolumn{5}{c}{3.16} \\
\hline
\end{tabular}

Keterangan: Angka pada kolom dan baris diikuti oleh huruf yang sama tidak berbeda nyata pada uji Scott-Knott dengan tingkat signifikasi 95\%.

Pada Tabel 3 dapat dilihat bahwa terdapat interaksi tiap perlakuan pada parameter volume akar umur tanaman 4mst. Nilai CV pada parameter ini cukup kecil, yang menandakan bahwa tidak banyak faktor lingkungan yang mempengaruhi pertumbuhan tanaman. Secara garis besar dapat dikatakan bahwa klon KK memiliki volume akar terkecil dibandingkan dengan keempat klon lainnya. Berdasarkan karakteristiknya, klon KK memerlukan kondisi lahan yang bertekstur liat sedang sampai berat dengan air cukup tersedia sehingga dengan kondisi kadar lengas yang kecil akan membuat pertumbuhan tanaman klon KK akan menunjukkan keragaan yang kurang memuaskan.

Tabel 4. Pengaruh persemaian pada penanaman di polybag terhadap volume akar umur $16 \mathrm{mspt}$ $\left(\mathrm{cm}^{3}\right)$

\begin{tabular}{ccccccc}
\hline $\begin{array}{c}\text { Kadar Lengas } \\
(\%)\end{array}$ & \multicolumn{5}{c}{ Klon } & \multirow{2}{*}{ Rerata } \\
\cline { 2 - 5 } & PS 862 & PS 864 & KK & BL & VMC 76-16 & \\
\hline 100 & $6.65 \mathrm{a}$ & $6.49 \mathrm{~b}$ & $6.29 \mathrm{~b}$ & $6.64 \mathrm{a}$ & $6.79 \mathrm{a}$ & 6.57 \\
80 & $6.34 \mathrm{~b}$ & $6.66 \mathrm{a}$ & $6.41 \mathrm{~b}$ & $6.79 \mathrm{a}$ & $6.73 \mathrm{a}$ & 6.59 \\
60 & $6.43 \mathrm{~b}$ & $6.80 \mathrm{a}$ & $6.35 \mathrm{~b}$ & $6.77 \mathrm{a}$ & $6.80 \mathrm{a}$ & 6.63 \\
40 & $6.33 \mathrm{~b}$ & 6.75 & $6.35 \mathrm{~b}$ & $6.78 \mathrm{a}$ & $6.88 \mathrm{a}$ & 6.62 \\
\hline Rerata & 6.44 & 6.67 & 6.35 & 6.75 & 6.80 & $(+)$ \\
\hline CV (\%) & & & & 1.50 & & \\
\hline
\end{tabular}

Keterangan: Angka pada kolom dan baris diikuti oleh huruf yang sama tidak berbeda nyata pada uji Scott-Knott dengan tingkat signifikasi 95\%.

Dari Tabel 4 dapat terlihat bahwa terdapat interaksi antar faktor perlakuan pada volume akar tanaman umur 16 mst. Nilai CV disini juga tergolong kecil yang menandakan seditnya faktor yang mempengaruhi pertumbuhan tanaman. Klon Kidang Kencana memiliki rerata yang terendah dibandingkan klon lainnya, dengan nilai terendah pada kadar lengas $100 \%$ yaitu berkisar $6,29 \mathrm{~cm}^{3}$. Dilihat dari data deskripsi varietas yang dikeluarkan oleh P3Gl, klon KK cenderung tidak toleran dibandingkan dengan klon lainnya yang digunakan pada percobaan ini. Seharusnya panjang ataupun volume akar akan lebih 
tinggi dikarenakan volume akar pada tanaman menurun sebagai respons terhadap kekurangan air. Faktor lain yang dapat mempengaruhi hal tersebut yaitu kondisi lingkungan ditumbuhi gulma dan media tanam yang hanya menggunakan polibag dengan ukuran kecil menghambat pertumbuhan akar tidak maksimal. Kehadiran gulma pada pertanaman akan menimbulkan kompetisi yang sangat serius dalam mendapatkan air, hara, cahaya matahari dan tempat tumbuh, dampaknya hasil tanaman tidak mampu menunjukkan potensi yang sebenarnya.

Bobot segar akar digunakan untuk mengetahui kemampuan tanaman dalam menyerap air. Kebutuhan tanaman akan air dapat dipenuhi dengan jalan penyerapan oleh akar. Kadar air di dalam tanah dan kemampuan akar untuk menyerap air sangat mempengaruhi besarnya air yang diserap oleh akar sehingga kemampuan akar dalam menyerap air tersebut sangat mempengaruhi bobot segar akar.

Bobot kering akar mengindikasikan kemampuan suatu tanaman untuk menyerap air, karena tanaman yang memiliki bobot kering akar yang tinggi memiliki perakaran yang lebih besar serta memiliki tingkat toleransi yang lebih tinggi terhadap kekeringan dibandingkan dengan tanaman dengan bobot kering akar yang rendah. Pada saat kekurangan air pertumbuhan sistem perakaran umumnya meningkat, sedangkan pertumbuhan tajuk menurun. Tanaman yang lebih mementingkan pertumbuhan akar daripada pertumbuhan tajuk, akan memiliki kemampuan yang lebih baik untuk bertahan pada kondisi kekurangan air.

Tabel 5. Pengaruh kadar lengas dan klon tebu pada tahap persemaian terhadap bobot segar akar 4 mst (g)

\begin{tabular}{ccccccc}
\hline $\begin{array}{c}\text { Kadar Lengas } \\
(\%)\end{array}$ & \multicolumn{5}{c}{ Klon } & \multirow{2}{*}{ Rerata } \\
\cline { 2 - 6 } & PS 862 & PS 864 & KK & BL & VMC 76-16 & \\
\hline 100 & 1.08 & 1.08 & 1.06 & 1.08 & 1.09 & $1.08 \mathrm{a}$ \\
80 & 1.06 & 1.05 & 1.03 & 1.04 & 1.05 & $1.05 \mathrm{~b}$ \\
60 & 1.04 & 1.04 & 1.03 & 1.10 & 1.04 & $1.05 \mathrm{~b}$ \\
40 & 1.04 & 1.05 & 1.04 & 1.05 & 1.04 & $1.04 \mathrm{~b}$ \\
\hline Rerata & $1.06 \mathrm{a}$ & $1.05 \mathrm{a}$ & $1.04 \mathrm{a}$ & $1.07 \mathrm{a}$ & $1.06 \mathrm{a}$ & $(-)$ \\
\hline CV (\%) & & & \multicolumn{5}{c}{2.98} & & \\
\hline
\end{tabular}

Keterangan: Angka pada kolom atau baris diikuti oleh huruf yang sama tidak berbeda nyata pada uji Scott-Knott dengan tingkat signifikasi 95\%

Kadar lengas $100 \%$ memiliki nilai paling tinggi dibandingkan kadar lengas (Tabel 5). Hal itu berarti penurunan kadar air pada tanaman mampu mempengaruhi proses perkecambahan tanaman. Hasil yang sama juga ditunjukkan pada bobot kering akar. Berdasarkan data diatas dapat dilihat bahwa pengurangan kadar lengas berpengaruh 
pada pertumbuhan akar tanaman. Kondisi optimal $100 \%$ tetap menjadi kondisi yang ideal bagi tanaman tebu untuk tumbuh. Namun kondisi kadar lengas $80 \%$ baik pada bobot segar dan bobot kering menunjukkan hasil yang tidak normal dengan bobot yang lebih kecil dibandingkan bobot pada kadar lengas $60 \%$. Faktor-faktor yang mampu mempengaruhi selama penelitian yaitu pengaturan penyiraman yang error baik saat penimbangan maupun saat pemberian, kondisi cahaya matahari yang tak menentu dan posisi penempatan bak yang lebih sering terpapar cahaya matahari dibandingkan dengan kadar lengas lainnya.

Berdasarkan hasil dari uji korelasi diatas parameter yang menunjukkan korelasi yang nyata yaitu bobot segar batang tahap perkecambahan dengan bobot kering akar tahap pertumbuhan tunas, bobot segar batang tahap perkecambahan dengan bobot kering daun tahap pertumbuhan tunas, bobot kering batang tahap perkecambahan dengan bobot kering akar tahap pertumbuhan tunas, dan terakhir bobot kering batang tahap perkecambahan dengan bobot kering daun tahap pertumbuhan tunas. Keseluruhan parameter yang memiliki korelasi nyata terlihat pada hasil yang berbeda nyata pada faktor klonnya. Pada kenaikan nilai parameter bobot segar batang tahap perkecembahan diikuti dengan kenaikan nilai dari bobot kering akar tahap pertumbuhan tunas dan bobot kering daun tahap pertumbuhan tunas. Begitu pula pada parameter bobot kering batang tahap perkecambahan, kenaikan nilainya diikuti pula dengan kenaikan nilai bobot kering akar tahap pertumbuhan tunas dan nilai bobot kering daun tahap pertumbuhan tunas.

Tabel 6. Nilai korelasi antara fase perkecambahan dan tahap pertumbuhan tunas 


\begin{tabular}{lcccccccc}
\hline & BSA1 & BSD1 & BSB1 & BKA1 & BKD1 & BKB1 & VA1 & PA1 \\
\hline BSA2 & 0.03 & 0.23 & 0.44 & 0.27 & 0.53 & 0.46 & 0.21 & 0.03 \\
BSD2 & 0.03 & -0.12 & -0.07 & -0.04 & -0.24 & -0.09 & -0.20 & 0.03 \\
BSB2 & 1.00 & 0.27 & 0.44 & 0.94 & 0.26 & 0.48 & 0.29 & 0.59 \\
BKA2 & 0.30 & 1.00 & 0.69 & 0.27 & 0.87 & 0.61 & 0.29 & 0.51 \\
BKD2 & 0.44 & 0.66 & 1.00 & 0.38 & 0.53 & 0.89 & 0.31 & 0.52 \\
BKB2 & 0.94 & 0.25 & 0.38 & 1.00 & 0.25 & 0.46 & 0.28 & 0.58 \\
VA2 & 0.16 & -0.03 & 0.17 & 0.17 & -0.01 & 0.21 & 0.39 & 0.12 \\
PA2 & 0.11 & 0.31 & 0.20 & 0.15 & 0.28 & 0.16 & 0.47 & 0.16 \\
\hline
\end{tabular}

Keterangan: Angka dengan tanda warna merah merupakan parameter yang memiliki korelasi positif

BSA 1 : Bobot Segar Akar Tahap Perkecambahan BSA2 : Bobot Segar Akar Tahap Pertumbuhan

BSD1 : Bobot Segar Daun Tahap Perkecambahan $\quad$ BSD2 : Bobot Segar Daun Tahap Pertumbuhan

BSB1 : Bobot Segar Batang Tahap Perkecambahan BSB2 : Bobot Segar Batang Tahap Pertumbuhan

BKA1 : Bobot Kering Akar Tahap Perkecambahan BKA2 : Bobot Kering Akar Tahap Pertumbuhan

BKD1 : Bobot Kering Daun Tahap Perkecambahan BKD2 : Bobot Kering Daun Tahap Pertumbuhan

BKB1 : Bobot Kering Batang Tahap Perkecambahan BKB2 : Bobot Kering Batang Tahap Pertumbuhan

VA1 : Volume Akat Tahap Perkecambahan VA2 : Volume Akar Tahap Pertumbuhan

PA1 : Panjang Akar Tahap Perkecambahan PA2 :Panjang Akar Tahap Pertumbuhan

Dalam menentukan kemampuan klon tebu terhadap pengaruh kadar lengas, dilakukan perhitungan regresi untuk melihat tingkat kebutuhan air tanaman pada gaya berkecambah optimal tanaman. Oleh karena itu, dilakukan analisis regresi lanjutan dengan menggunakan gaya berkecambah tiap faktor klonnya. Hasil yang didapatkan sebagai berikut.

Berdasarkan Grafik 1 nilai $R^{2}$ nya yaitu 0,893 . Hal itu menandakan bahwa simpangan baku cukup kecil. Pada gaya berkecambah 100\% tanaman tebu membutuhkan kadar lengas berkisar pada $80 \%$, yang menandakan bahwa tebu tidak membutuhkan kondisi optimum 100\% kadar lengas untuk menumbuhkan tebu secara maksimal. Lalu pada gaya berkecambah $50 \%$ kadar lengas yang dibutuhkan yaitu sekitar $65 \%$, hal ini menandakan bahwa kebutuhan air cukup tinggi dan signifikan perbedaan gaya berkecambah apabila kadar lengas diturunkan dari 85\% hingga 65\%. Meskipun pada penelitian ini klon Kidang Kencana menunjukkan gaya berkecambah yang cukup rendah yaitu sekitar $40 \%$ pada kadar lengas $40 \%$, namun secara keseluruhan tanaman tebu cukup rentan apabila kadar lengas diturunkan hingga $40 \%$. 
Bibiana et al., / Vegetalika. 2019. 8(4): 251-262

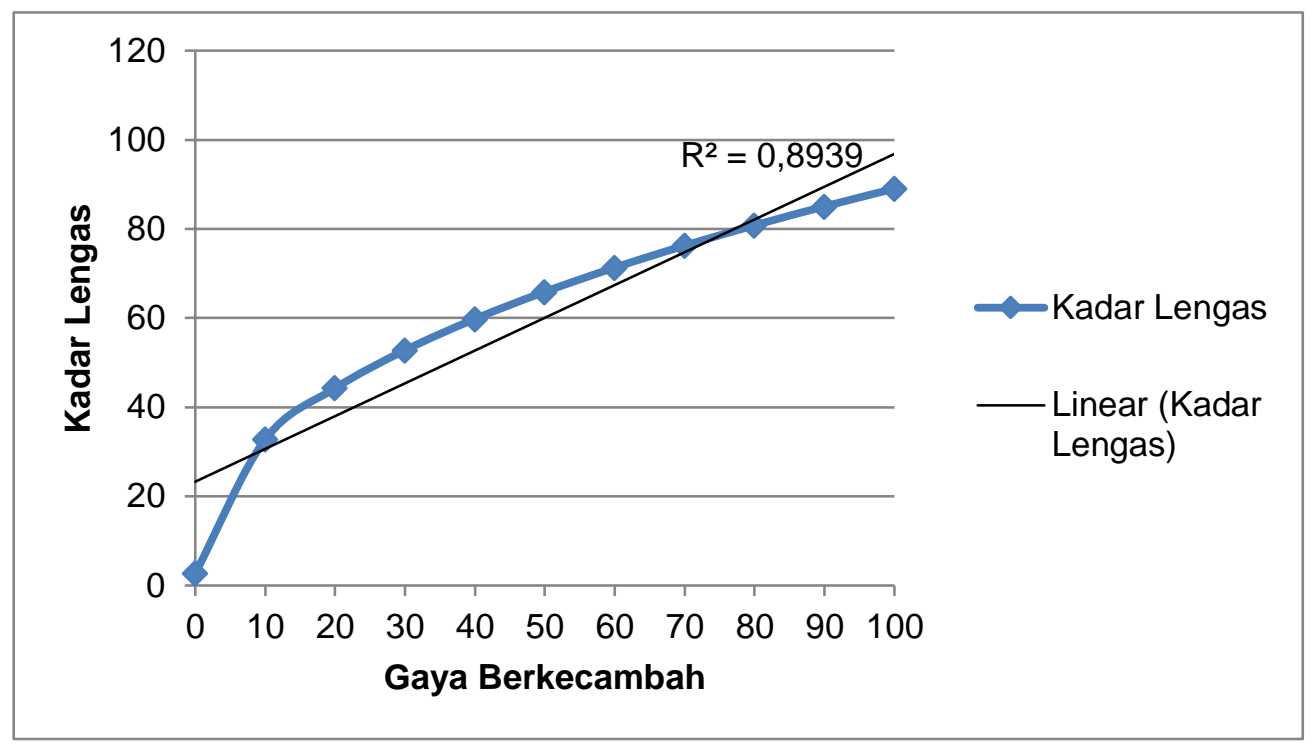

Grafik 1. Perbandingan daya tumbuh tanaman pada pengaruh kadar lengas

\section{KESIMPULAN}

1. Pengaruh kadar lengas tanah dapat dilihat dari beberapa sifat yang menunjukkan adanya perubahan nilai tiap penurunan perlakuan kadar lengas. Pada beberapa klon, menunjukkan nilai yang cukup berbeda nyata ketika kadar lengas tanah diturunkan tiap $20 \%$.

2. Pada proses persemaian atau perkecambahan, kadar lengas cukup mempengaruhi beberapa proses pertumbuhan tebu ditandai dengan menurunnya kemampuan tumbuh tanaman. Klon Kidang Kencana terlihat mempunyai tingkat ketahanan yang paling rendah dibandingkan keempat klon lainnya.

3. Pada proses pertumbuhan tunas terlihat bahwa ketika kondisi lingkungan optimal, tanaman tebu memiliki proses penyembuhan yang cukup cepat, sehingga semua parameter menunjukkan adanya peningkatan pertumbuhan.

4. Klon yang menunjukkan ketahanan terhadap pengurangan kadar lengas tanah yaitu klon PS 862 dan klon VMC 76-16 berdasarkan gaya berkecambah, jumlah daun, panjang akar, volume akar, dan bobot segar akar pada kondisi kadar lengas $40 \%$. 
Sesuai dengan karakteristiknya, klon tersebut mampu tahan pada kondisi drainase pengairan yang buruk.

\section{DAFTAR PUSTAKA}

Gardner, F.P., R. Brent P., Roger L.M. 1985. Fisiologi Tanaman Budidaya. Terjemahan oleh Herawati Susilo. UI-Press, Jakarta.

Mulyani A, Syarwani M. 2013. Karakteristik dan Potensi Lahan Sub Optimal untuk Pengembangan Pertanian di Indonesia. Prosiding Seminar Nasional Lahan Suboptimal "Intensifikasi Pengelolaan Lahan Sub-optimal dalamRangka Mendukung Kemandirian Pangan Nasional", Palembang 20-21 September 2013.

Onwueme, I. C. 1978. The Tropical Tuber Crops: Yams, Cassava, Sweetpotato, and Cocoyam. John Wiley. 291 p.

Riajaya, Prima Diarini. 2016. Kebutuhan air tanaman tebu. http://balittas.litbang.pertanian.go.id/index.php/produk/alat-dan-mesin/60-infoteknologi/380-kebutuhan-air-tanaman-tebu. Diakses pada tanggal 3 Mei 2017.

Wijayanti, W.A. 2008. Pengelolaan tebu (Saccharum officinarum L.) di Pabrik Gula Tjoekir PTPN X, Jombang, Jawa Timur; studi kasus pengaruh bongkar ratoon terhadap peningkatan produktivitas tebu.Skripsi Sarjana Fakultas Pertanian Institut Pertanian Bogor. Bogor. 